\title{
PENGARUH RESILIENSI KARYAWAN TERHADAP KINERJA KARYAWAN MELALUI KEPUASAN HIDUP
}

\author{
Qikki Ocktafian \\ Universitas Negeri Surabaya \\ qikki.17080574106@mhs.unesa.ac.id
}

\begin{abstract}
The focus of this study is to discuss the effect of employee resilience on employee performance with life satisfaction as a mediation variable. The object of this research is the nurses at Rumah Sakit Islam Surabaya, with the respondents is 71 nurses. This study used quantitative methods to process questionnaires that have previously been distributed online. Statistical analysis uses Partial Least Square with smartPLS 3.3 program. This study shows a positive and significant influence between employee resilience to performance and employee life satisfaction. However, there was no significant influence found between satisfaction on employee performance. Furthermore, the relationship between employee resilience and employee performance through life satisfaction variables as mediation was not found to have a significant effect. The implication of this research is that to maintain and improve the performance of nurses, it is necessary to have adaptive and resilient nurses in facing various challenges in the world of work, regardless of the level of life satisfaction of nurses.
\end{abstract}

Keywords: employee performance; employee resilience; life satisfaction

\section{PENDAHULUAN}

Pada awal tahun 2020 pandemi Covid-19 telah mengejutkan dunia yang dimulai dari satu lokasi kemudian menyebar dengan cepat ke seluruh dunia baik dalam dimensi spasial maupun temporal dengan karakteristik kejadian yang tidak terduga (Li, 2020). Pandemi Covid-19 mengakibatkan economic shock serta memengaruhi ekonomi dari berbagai cakupan skala nasional hingga ekonomi secara global (Taufik \& Ayuningtyas, 2020). Dampak dari pandemi Covid-19 yang muncul pada awal tahun 2020 mengakibatkan adanya perubahan tatanan kehidupan sosial serta berakibat pada penurunan kinerja ekonomi sebagian besar negara termasuk Indonesia (Badan Pusat Statistik, 2020).

Akibat dari fenomena ini aktivitas para pelaku bisnis menjadi sangat terbatas setelah diterapkannya beberapa kebijakan pemerintah seperti work from home (WFH), pengurangan jam kerja serta pembatasan sosial berskala besar (PSBB) bagi masyarakat dalam rangka mengendalikan sebaran virus Covid-19 agar tidak menjadi lebih besar dan berkepanjangan (Mungkasa, 2020). Sehingga adanya perubahan pola kerja yang dialami oleh karyawan berpotensi memengaruhi keberhasilan suatu organisasi dalam mencapai tujuannya (Sutrisno, 2009). Di mana perubahan pola kerja yang terjadi dapat memberikan pengaruh secara langsung atau tidak langsung bagi kondisi psikis karyawan untuk menjalankan pekerjaan secara optimal, sehat, aman, dan nyaman (Sedarmayanti, 2009)

Berubahnya keadaan operasional bisnis di masa pandemi Covid-19 telah menuntut karyawan perusahaan untuk beradaptasi dengan kondisi waspada dan perasaan cemas secara terus menerus yang dapat menimbulkan efek negatif bagi kesehatan dan kinerja karyawan (Dewayani, 2020). Oleh karena itu dalam menghadapi ambiguitas keadaan, perusahaan harus berperan dalam menjaga kesehatan mental karyawannya serta memerhatikan faktor-faktor yang dapat berpengaruh negatif terhadap performa kerja para karyawannya, sehingga perusahaan dituntut menjadi lebih tangguh untuk menghadapi berbagai potensi situasi krisis yang terjadi (Linnenluecke, 2017).

Menurut Cooper et al. (2014) ketahanan karyawan atau resiliensi karyawan adalah kemampuan seseorang untuk bangkit kembali dari kemunduran dengan tetap efektif dalam menghadapi berbagai tuntutan yang berat dan keadaan sulit serta tumbuh lebih kuat dalam prosesnya. Bonnano (2005) menyatakan resiliensi karyawan adalah kemampuan individu untuk memertahankan stabilitas diri 
dalam menghadapi peristiwa yang sangat menegangkan atau traumatis menuju perubahan positif setelah kejadian buruk. Tingkat ketahanan yang tinggi dari seorang pengusaha atau karyawan akan membuatnya menjadi lebih adaptif dalam menghadapi berbagai ambiguitas keadaan seperti saat ini termasuk sifat tahan banting, sikap optimisme serta pemecahan masalah (Ayala \& Manzano, 2014). Hal tersebut sesuai dengan pendapat Wang et al. (2014) bahwa dengan adanya karyawan yang tangguh akan mampu merespon secara positif dan kompeten ketika menghadapi kesulitan serta berperan sangat penting untuk kelangsungan hidup organisasi untuk jangka waktu panjang.

Berbeda dengan hasil penelitian sebelumnya mengenai ketahanan karyawan yang berpengaruh positif terhadap kinerja, Hallak et al. (2018) menguji variabel resiliensi karyawan terhadap kinerja karyawan restoran di Australia mengemukakan bahwa resiliensi tidak berdampak secara positif dengan kinerja karyawan dan manajer restoran. Lhalloubi \& Ibnchahid (2020) mengungkapkan jika tidak ditemukan pengaruh positif dan signifikan antara ketahanan dengan kinerja karyawan dan manajer. Hasil penelitian tersebut bertentangan dengan penelitian sebelumnya, jika faktor resiliensi memiliki pengaruh positif dan signifikan terhadap kinerja pegawai (Liu, 2018).

Prayag et al. (2019) mengungkapkan bahwa faktor resiliensi berpengaruh secara positif dan signifikan terhadap kepuasan hidup. Hal tersebut didukung oleh Hayat et al. (2016) di mana resiliensi secara signifikan berhubungan positif dengan kepuasan hidup, karena pengalaman individu secara psikologis dapat memengaruhi seseorang ketika menghadapi kondisi hidup yang sulit. Sehingga dengan adanya karyawan yang tangguh akan cenderung memiliki kepuasan hidup yang lebih tinggi (Prayag et al., 2019).

Jones (2006) mengungkapkan jika meningkatnya kepuasan hidup akan berdampak secara positif dan signifikan terhadap ukuran kinerja individu dalam organisasi. Hasil yang sama juga ditemukan Prajogo (2016) di mana kepuasan hidup berpengaruh positif terhadap kinerja, sehingga karyawan yang memiliki tingkat kepuasan hidup lebih besar akan membuat kinerjanya menjadi lebih baik sebab individu yang merasa puas akan menggunakan energi terbaiknya dalam melakukan pekerjaannya.

Pengaruh positif dan signifikan antara variabel kepuasan hidup dengan kinerja ternyata bertentangan dengan hasil penelitian Clohessy et al. (2020) dari studi yang dilakukan kepada karyawan di Irlandia menunjukkan jika kepuasan hidup tidak berpengaruh terhadap kinerja karyawan dalam organisasi. Hal itu memerkuat temuan Chughtai (2019) di mana tidak terdapat pengaruh positif dan signifikan secara langsung antara variabel kepuasan hidup terhadap kinerja karyawan perusahaan di Pakistan.

Berdasarkan berbagai sumber literatur, adanya research gap, serta melihat dampak dari fenomena Covid-19 yang memengaruhi pola kerja para karyawan, maka tujuan penelitian ini adalah untuk menganalisis serta menguji hubungan dari variabel resiliensi karyawan terhadap kinerja karyawan melalui variabel kepuasan hidup. Obyek penelitian ini adalah perawat yang bertugas di Rumah Sakit Islam Surabaya, di mana ketika pandemi Covid-19 dibutuhkan peran penting rumah sakit sebagai tempat rujukan utama yang tidak lepas dari peran besar dari tenaga kesehatan yang melakukan penanganan terhadap pasien sebagai titik kontak pertama bagi pasien yang terkonfirmasi virus Covid19.

\section{KAJIAN PUSTAKA DAN PENGEMBANGAN HIPOTESIS}

\section{Resiliensi Karyawan}

Menurut McNaughton dan Gray (2017) resiliensi atau ketahanan atau resilience (dalam bahasa inggris) diadopsi dari bahasa latin yaitu resilire, yang bermakna memantul atau bangkit kembali. Pada awalnya Holling (1973) mengungkapkan bahwa konstruksi dari resiliensi ini awalnya diperiksa dalam ilmu ekologi yaitu mengenai hubungan timbal balik antara makhluk hidup dengan lingkungan sekitarnya. Limnios et al. (2014) kemudian mengartikan resiliensi dari sistem sosio-ekologi sebagai besarnya gangguan yang dapat ditoleransi oleh suatu sistem. Dari beberapa pendapat tersebut Hallak et al. (2018) mengungkapkan bahwa saat ini resiliensi telah diperiksa sebagai bentuk organisasi yang tangguh, komunitas yang tangguh serta pengusaha yang tangguh. Selanjutnya Cooper et al. (2014) 
mendefinisikan resiliensi dalam konteks lingkungan perusahaan sebagai kemampuan individu untuk bangkit kembali dari kemunduran dengan tetap efektif dalam menghadapi berbagai tuntutan yang berat dan keadaan sulit, serta tumbuh lebih kuat dalam prosesnya. Sejalan dengan itu Wang et al. (2014) mengungkapkan bahwa adanya tenaga kerja yang tangguh akan mampu merespon secara positif dan kompeten dalam menghadapi kesulitan serta sangat penting untuk menjaga kelangsungan hidup organisasi dan kemakmuran di masa depan. Seperti pendapat Green et al. (1999) di mana resiliensi merupakan kemampuan untuk mengatasi berbagai hambatan dan kesulitan dalam menghadapi besarnya risiko yang dialami untuk menjadi sukses. Athota et al. (2020) juga mengungkapkan bahwa faktor resiliensi dapat berperan sebagai kunci sebab interaksi masyarakat secara global telah berkontribusi pada peningkatan aktivitas kerja yang signifikan dengan menuntut individu untuk menjadi lebih tangguh. Selain itu Reivich \& Shatte (2002) menyatakan bahwa resiliensi secara alami dapat memengaruhi individu dari segi perilaku di tempat kerja, kesehatan mental, kesehatan fisik, serta kualitas hubungan individu. Berdasarkan uraian dari berbagai literatur di atas dapat dikatakan bahwa resiliensi merupakan kemampuan karyawan dalam menghadapi berbagai tantangan dan tekanan di tempat kerja sehingga dapat terus bertahan, beradaptasi serta berkembang untuk bangkit dari situasi yang sulit.

\section{Kinerja Karyawan}

Mathis dan Jackson (2008) mengartikan kinerja karyawan sebagai kontribusi dari karyawan yang diberikan kepada perusahaan yang kemudian diidentifikasi berdasarkan hasil kerja karyawan tersebut. Senada dengan pernyataan tersebut Mangkunegara (2010) mengungkapkan jika kinerja karyawan merupakan hasil kerja baik secara kualitas maupun kuantitas yang dicapai oleh seorang karyawan dalam melaksanakan tugasnya sesuai dengan tanggung jawab yang diberikan kepadanya. Sedangkan Rahman et al. (2020) menjelaskan bahwa kinerja merupakan pencapaian prestasi kerja baik secara kualitas maupun kuantitas yang telah dilaksanakan sesuai dengan tujuan kerja yang telah ditentukan oleh perusahaan. Oleh karena itu kinerja dapat diartikan sebagai hasil yang diberikan untuk organisasi sesuai dengan tujuan organisasi (Kistyanto et al., 2018). Sementara itu Ong \& Mahazan (2020) mendefinisikan kinerja sebagai hasil dari peningkatan kompetensi karyawan untuk berkembang. Lebih lanjutnya performa atau kinerja merupakan keluaran dari suatu proses (Nurlaila, 2010). Menurut Sonnentag et al (2008) kinerja karyawan merupakan sebuah proses yang berkaitan dengan tindakan seseorang dalam menyelesaikan pekerjaannya. Hal itu mengacu pada tindakan atau perilaku di bawah kendali individu, yang berkontribusi pada tujuan organisasi dan yang dapat diukur melalui tingkat kompetensi individu (Saoussany, 2018). Sebelumnya Welbourne et al. (1998) mendefinisikan kinerja adalah proses dari sebuah jabatan tertentu untuk memenuhi tuntutan tugas maupun tanggung jawab. Sementara Williams dan Anderson (1991) mengungkapkan bahwa kinerja sebagai bentuk komitmen tanggung jawab kepada tugasnya, dan memberikan kontribusi yang tidak terbatas serta memengaruhi penilaian pimpinan, dan kontribusi yang secara spontan dilakukan tanpa perintah. Berdasarkan referensi dari uraian literatur di atas dapat diartikan bahwa kinerja karyawan adalah kontribusi karyawan yang diberikan kepada perusahaan serta dapat diidentifikasi berdasarkan pencapaian kerja karyawan tersebut.

\section{Kepuasan Hidup}

Andrews \& Withey (1976) mengemukakan jika kepuasan hidup merupakan komponen kognitif dalam subjective well being. Diener \& Lucas (2000) menyatakan bahwa subjective well being mengacu pada kepercayaan atau perasaan subjektif individu yang merasa bahwa kehidupannya berjalan dengan baik. Chaplin (2006) mengungkapkan bahwa kepuasan hidup adalah suatu keadaan individu dalam merasakan senang serta sejahtera sebab telah mencapai sebuah tujuan atau sasarannya. Kemudian Diener et al. (1985) mengartikan kepuasan hidup adalah mengenai penilaian terhadap kualitas kehidupan individu yang dinilai secara menyeluruh berdasarkan kriteria-kriteria yang ditetapkannya sendiri. Senada dengan hal tersebut Margolis et al. (2019) mengartikan bahwa kepuasan hidup adalah evaluasi kehidupan pribadi yang berubah sesuai dengan persepsi masing-masing individu. Dalam konteks sumber daya manusia Berlemann (2016) mengungkapkan bahwa dalam literatur ekonomi, kebahagiaan dan kepuasan hidup biasanya diukur sebagai proksi untuk kesejahteraan individu. Kepuasan hidup karyawan tersebut ditentukan oleh kondisi fisik, dan mental yang bergantung pada 
berbagai indikator seperti pendapatan, hubungan dengan orang lain, pendidikan, kesehatan, kualitas lingkungan, kepercayaan pada orang lain, layanan yang diberikan, keamanan dan keseimbangan kehidupan kerja yang secara bersama-sama menentukan sejauh mana karyawan secara komparatif menilai kualitas hidupnya (Demiral, 2018). Oleh karenanya kepuasan hidup umumnya mengacu pada ringkasan evaluasi tentang hidup seseorang secara keseluruhan yang biasanya akan mencakup kepuasan hidup pada saat dahulu, saat ini, serta harapan di waktu yang akan datang (Diener et al., 1985). Berdasarkan beberapa pendapat para ahli serta dari litaratur-literatur yang mendukung dapat dikatakan bahwa kepuasan hidup adalah penilaian secara menyeluruh antara pemenuhan kebutuhan dan harapan dalam kehidupan individu yang berlandaskan kriteria tertentu yang ditetapkannya sendiri.

\section{Hubungan Antar Variabel}

Dalam lingkungan bisnis yang sangat kompetitif penuh dengan perubahan seperti saat ini, resiliensi karyawan memainkan peran penting sebagai kemampuan untuk meningkatkan kinerja individu dan organisasi (Liu, 2018). Hal itu terjadi karena ketangguhan karyawan sebagai sumber daya psikologis dari individu yang dapat digunakan untuk mengatasi stres dari situasi kerja bertekanan tinggi yang pada akhirnya dapat mendorong keterlibatan positif dalam menyelesaikan tugas yang sulit (Bardoel et al., 2014). Menurut Liu (2018) resiliensi karyawan memberikan dampak secara signifikan positif terhadap kinerja pegawai bank di China. Athota et al. (2020) mengungkapkan jika terdapat pengaruh positif serta signifikan antara resiliensi dengan kinerja pegawai Australia dan India. Temuan tersebut juga diperkuat Walpita (2020) apabila tingkat resiliensi semakin tinggi maka kinerja dari seorang perawat di kota Colombo Sri Lanka cenderung juga akan semakin tinggi. Hal itu disebabkan tingginya tingkat resiliensi dapat mengurangi dampak negatif di tempat kerja seperti stres, kelelahan, depresi, dan kecemasan (Gito et al., 2013). Namun Lhalloubi \& Ibnchahid (2020) menunjukkan resiliensi karyawan tidak berpengaruh positif terhadap kinerja karyawan dan manajer. Hallak et al. (2018) juga menunjukkan antara resiliensi terhadap kinerja pegawai tidak terdapat hubungan signifikan positif.

\section{H1: Resiliensi karyawan memiliki pengaruh positif dan signifikan terhadap kinerja karyawan.}

Luthans et al. (2007) menyatakan bahwa strategi peningkatan resiliensi secara proaktif dan reaktif di tempat kerja dapat berkontribusi terhadap kepuasan hidup sehingga resiliensi karyawan memengaruhi kebahagiaan individu di tempat kerja. Memerluas argumen tersebut, Prayag et al. (2019), mengungkapkan resiliensi pada diri seseorang dapat memberikan pengaruh positif terhadap kepuasan hidup pemilik atau manajer bisnis. Sejalan dengan itu resiliensi juga ditemukan untuk memprediksi kepuasan hidup karena dapat bekerja sebagai perisai seseorang dalam menghadapi berbagai kesulitan (Langer, 2004). Cohn et al. (2009) menunjukkan peran dari resiliensi sebagai mediasi antara kebijaksanaan dan kepuasan hidup seseorang. Menurut Hall et al. (2016) faktor resiliensi yang dimiliki karyawan dapat digunakan untuk menyoroti kesejahteraan karyawan tersebut. Adanya tingkat resiliensi yang tinggi dapat memermudah proses berkembang dari seseorang melalui pengalaman hidup dan interaksi dengan lingkungan kerja (Fisher et al., 2016). Namun berbeda dengan hasil tersebut, Hayat et al., (2016) mengungkapkan jika resiliensi tidak memiliki pengaruh positif dengan kepuasan hidup.

H2 : Resliensi karyawan memiliki pengaruh positif dan signifikan terhadap kepuasan hidup.

Jones (2006) mengungkapkan jika kepuasan hidup memiliki korelasi positif dengan kinerja di mana variabel kepuasan hidup dapat memprediksi kinerja karyawan pada pekerjaannya sehingga karyawan yang bahagia dengan kehidupannya cenderung lebih akan produktif di tempat kerja. Hal itu dikarenakan emosi kebahagiaan seseorang bisa memainkan peran kunci dalam meningkatkan kinerja mereka (Cropanzano \& Wright, 2001). Kepuasan hidup dapat mengarah pada kinerja yang lebih baik (Greguras \& Diefendorff, 2010). Prajogo (2016) juga mengungkapkan kepuasan hidup berpengaruh positif terhadap kinerja pegawai di mana ketika seseorang memiliki kepuasan hidup yang lebih besar, maka kinerja yang dimiliki dapat meningkat. Hal tersebut terjadi karena orang yang puas akan menggunakan energi terbaiknya dalam melaksanakan pekerjaannya. Namun Chughtai (2019) tidak menemukan pengaruh signifikan positif antara variabel kepuasan hidup dengan kinerja karyawan. 
H3 : Kepuasan hidup memiliki pengaruh positif dan signifikan terhadap kinerja karyawan.

Prayag et al. (2019) menunjukkan bahwa kepuasan hidup berhubungan secara positif dalam memediasi variabel resiliensi terhadap ketahanan psikologis karyawan dalam meningkatkan ketahanan organisasi. Menurut Erdogan et al. (2012) jika faktor kepuasan hidup bisa menjadi prediktor yang lebih kuat terhadap kinerja dibandingkan dengan faktor kepuasan kerja. Staw et al. (1994) juga mengemukakan bahwa kepuasan hidup akan menjadi prediktor yang lebih baik daripada variabel kepuasan kerja. Sejalan dengan hal tersebut Jones (2006) menunjukkan bahwa variabel kepuasan hidup secara signifikan berpengaruh secara positif pada prediksi OCB dan kinerja karyawan. Sehingga hasil tersebut dapat mendasari variabel kepuasan hidup sebagai variabel mediasi dalam mengukur resiliensi karyawan terhadap kinerja karyawan.

H4 : Resiliensi karyawan berpengaruh positif dan signifikan terhadap kinerja karyawan melalui variabel kepuasan hidup.

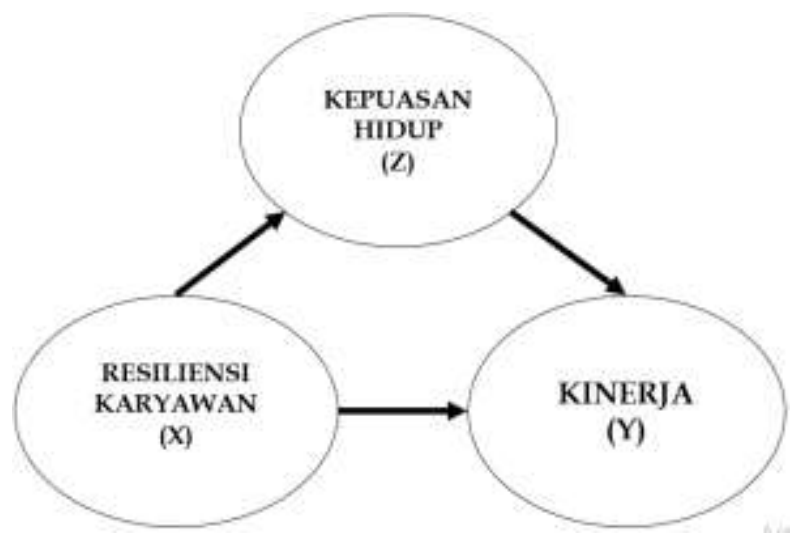

Gambar 1. KERANGKA KONSEPTUAL

\section{METODE PENELITIAN}

Metode kuantitatif digunakan dalam penelitian ini. Hubungan antar variabel yang diteliti dalam penelitian ini adalah pengaruh resiliensi karyawan terhadap kinerja karyawan melalui kepuasan hidup. Pengambilan data dilakukan secara online mengunakan kuisioner dari google form yang dibagikan melalui media sosial kepada responden. Penelitian ini menggunakan sampel sebanyak 71 perawat dari Rumah Sakit Islam Surabaya. Pengambilan sampel dilakukan dengan teknik non probability sampling menggunakan model Quota Sampling (sampel kuota) yaitu para perawat yang bekerja di Rumah Sakit Islam Surabaya. Teknik analisis data menggunakan Partial Least Square dengan aplikasi SmartPLS 3.3.

\section{HASIL DAN PEMBAHASAN}

\section{Karakteristik Responden}

Berdasarkan pengumpulan dan pengolahan data responden yang telah dilakukan terhadap perawat dari Rumah Sakit Islam Surabaya, diperoleh total 71 responden yang terkumpul. Karakteristik responden yang berjenis kelamin perempuan sebanyak $56(78,9 \%)$ perawat, sementara 15 perawat $(21,1 \%)$ adalah berjenis kelamin laki-laki. Usia rata-rata responden 18-22 tahun (43,7\%), kemudian berdasarkan tingkat pendapatan rata-rata >Rp3.000.000 (36,6\%).

\section{Convergent Validity}

Berdasarkan gambar 2 nilai dari outer loadings pada setiap indikator di atas 0,50 di mana tersebut menunjukkan bahwa setiap indikator dikategorikan valid. Seluruh indikator tersebut dikategorikan valid apabila memiliki nilai korelasi lebih dari 0,70. Tetapi menurut Chin (1998) dalam Ghozali 
(2012:25) pada penelitian tahap awal jika nilai loadings antara 0,50 hingga 0,60 dianggap cukup (Ann et al., 2017).

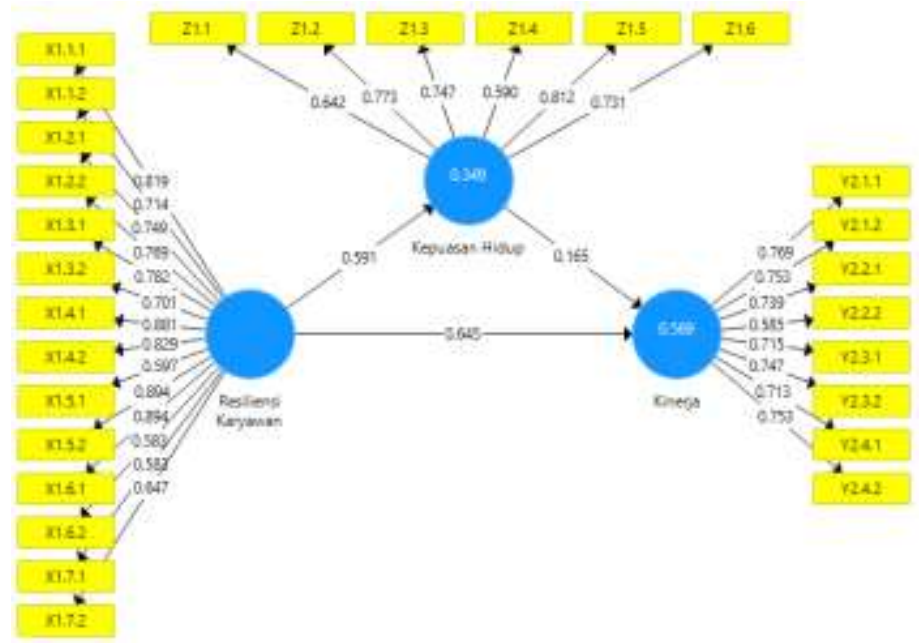

Sumber : Output SmartPLS 3.3

Gambar 2. UJI MEASUREMENT MODEL

\section{Composite Reliability}

Berdasarkan hasil pengujian diketahui besar nilai dari composite reliability variabel resiliensi karyawan sebesar 0,947, variabel kinerja karyawan sebesar 0,898 dan variabel kepuasan hidup sebesar 0,864 . Sehingga nilai composite reliability pada masing-masing variabel tersebut lebih dari 0,06 dan telah memenuhi standart composite reliability atau memiliki reliabilitas yang baik. Hal tersebut sesuai dengan pendapat Henseler et al. (2009) bahwa composite reliability dikatakan baik jika memiliki nilai di atas 0,60 (Budhiasa, 2016).

\section{Croanbach's Alpha}

Cronbach's alpha dapat memerkuat hasil uji reliabilitas dari hasil composite reliability sebelumnya serta untuk mengevaluasi internal consistency. Nilai croanbach's alpha untuk variabel resiliensi karyawan sebesar 0,939, variabel kinerja karyawan sebesar 0,872 dan variabel kepuasan hidup sebesar 0.818. Diketahui bahwa besar cronbach's alpha dari seluruh variabel dalam penelitian ini berada di atas 0,60. Dengan demikian model variabel tersebut telah memenuhi kriteria cronbach's alpha atau memiliki reliabilitas yang kuat. Hal itu sesuai dengan pendapat Nunally dan Berstein (1988) bahwa nilai cronbach's alpha dianggap reliabel apabila lebih besar dari 0,60 (Budhiasa, 2016).

\section{Analisis R-Square}

\section{Tabel 1.}

\section{R-SQUARE}

\begin{tabular}{cc}
\hline Variabel & R-Square \\
\hline Resiliensi karyawan & \\
Kinerja & 0,569 \\
Kepuasan Hidup & 0,349 \\
\hline
\end{tabular}

Sumber: Data diolah peneliti (2021)

Berdasarkan tabel 1, nilai $r$-square sebesar 0,569 yang berarti pengaruh resiliensi karyawan terhadap kinerja karyawan sebesar sebesar 56,9\% sedangkan 43,1\% diantaranya dipengaruhi faktor lain yang tidak terdapat dalam penelitian ini. Selanjutnya nilai $r$-square sebesar 0,349 menunjukkan bahwa pengaruh resiliensi karyawan terhadap kepuasan hidup sebesar 34,9\% sementara faktor lain yang tidak terdapat dalam penelitian ini mampu menjelaskan kepuasan hidup perawat Rumah Sakit Islam Surabaya sebesar $65,1 \%$. 


\section{Path Coefficients}

Tabel 2, besarnya nilai $t$-statistics pengaruh resiliensi karyawan terhadap kinerja karyawan sebesar $6,350 \geq 1,96$. Hal tersebut menunjukkan terdapat adanya pengaruh yang positif dan signifikan antara variabel resiliensi karyawan terhadap variabel kinerja. Nilai $t$-statistics pengaruh variabel resiliensi karyawan terhadap kepuasan hidup karyawan sebesar $6,958 \geq 1,96$. Hasil ini menujukkan adanya korelasi yang signifikan positif antara variabel resiliensi karyawan terhadap kepuasan hidup karyawan. Nilai $t$-statistics pengaruh kepuasan hidup terhadap kinerja karyawan sebesar 1,397 $\leq 1,96$. Artinya, tidak terdapat pengaruh yang signifikan antara variabel kepuasan hidup terhadap kinerja karyawan.

Tabel 2.

PATH COEFFICIENTS

\begin{tabular}{|c|c|c|c|c|}
\hline Hubungan antar variabel & $\begin{array}{c}\text { Original } \\
\text { Sample }\end{array}$ & T-Statistics & Keterangan & Keputusan \\
\hline $\begin{array}{l}\text { Resiliensi karyawan } \rightarrow \text { Kinerja } \\
\text { karyawan }\end{array}$ & 0,645 & 6,350 & $\begin{array}{c}\geq 1,96 \\
\text { (Signifikan) }\end{array}$ & $\begin{array}{l}\text { Hipotesis } \\
\text { diterima }\end{array}$ \\
\hline $\begin{array}{l}\text { Resiliensi karyawan } \rightarrow \text { Kepuasan } \\
\text { hidup }\end{array}$ & 0,591 & 6,958 & $\begin{array}{l}\geq 1,96 \\
\text { (Signifikan) }\end{array}$ & $\begin{array}{c}\text { Hipotesis } \\
\text { diterima }\end{array}$ \\
\hline Kepuasan Hidup $\rightarrow$ Kinerja karyawan & 0,165 & 1,397 & $\begin{array}{c}\leq 1,96 \\
\text { (Tidak signifikan) }\end{array}$ & $\begin{array}{l}\text { Hipotesis } \\
\text { ditolak }\end{array}$ \\
\hline
\end{tabular}

Sumber: output PLS (2021)

Berdasarkan tabel 3, hubungan secara langsung di antara variabel resiliensi karyawan terhadap kinerja karyawan sebesar 0,645 dan nilai t-statistics 6,350 yaitu lebih besar dari 1,96 yang berarti bahwa pengaruh langsung antara variabel resiliensi karyawan terhadap kinerja adalah secara signifikan positif. Sementara itu pengaruh secara tidak langsung di antara variabel resiliensi karyawan terhadap kinerja karyawan melalui kepuasan hidup sebesar 0,097 dan nilai $t$-statistics 1,339 yaitu kurang dari 1,96 yang menunjukkan bahwa pengaruh tidak langsung antara variabel resiliensi karyawan terhadap kinerja melalui kepuasan hidup tidak signifikan. Sehingga dapat diketahui bahwa kepuasan hidup tidak memediasi resiliensi karyawan terhadap kinerja karyawan.

Tabel 3.

HASIL INDIRRECT EFFECT

\begin{tabular}{lcccc}
\hline \multicolumn{1}{c}{ Hubungan antar variabel } & $\begin{array}{c}\text { Original } \\
\text { Sample }\end{array}$ & T-Statistics & Keterangan & Keputusan \\
\hline $\begin{array}{l}\text { Resiliensi karyawan } \rightarrow \text { Kinerja } \\
\text { karyawan }\end{array}$ & 0,645 & 6,350 & $\begin{array}{c}\geq 1,96 \\
\text { (Signifikan) }\end{array}$ & $\begin{array}{c}\text { Hipotesis } \\
\text { diterima }\end{array}$ \\
$\begin{array}{l}\text { Resiliensi karyawa } \rightarrow \\
\begin{array}{l}\text { Kepuasan hidup } \rightarrow \text { Kinerja } \\
\text { karyawan }\end{array}\end{array}$ & 0,097 & 1,339 & $\begin{array}{c}\leq 1,96 \\
\text { (Tidak } \\
\text { signifikan) }\end{array}$ & $\begin{array}{c}\text { Hipotesis } \\
\text { ditolak }\end{array}$ \\
\hline
\end{tabular}

Sumber: output PLS (2021)

\section{Pengaruh Resiliensi Karyawan terhadap Kinerja Karyawan}

Berdasarkan pengujian, resiliensi karyawan berpengaruh positif dan signifikan terhadap kinerja karyawan. Semakin tinggi tingkat resiliensi yang dimiliki perawat di Rumah Sakit Islam Surabaya maka kinerja perawat tersebut juga akan meningkat. Korelasi positif yang signifikan antara resiliensi terhadap kinerja didasarkan pada tingginya nilai kuisioner mengenai indikator kehidupan otentik perawat yang menunjukkan bahwa para perawat cenderung memegang teguh prinsip kerja ketika bertugas serta selalu memberikan kemampuan terbaiknya. Walpita (2020), jika resiliensi (ketahanan) 
pada perawat di Sri Lanka menunjukkan korelasi positif dan signifikan terhadap kinerja keperawatan secara keseluruhan.

Indikator interaksi secara kooperatif juga menunjukkan nilai yang tinggi di mana perawat di Rumah Sakit Islam Surabaya secara aktif saling memberikan dukungan antara satu dengan yang lain guna meningkatkan mutu pelayanan instansi seperti yang tercermin pada nilai dan budaya perusahaan di Rumah Sakit Islam Surabaya yang menjadi pedoman dan motivasi perawat dalam menjalankan tanggung jawabnya. Perawat Rumah Sakit Islam Surabaya memiliki jaringan sesama perawat yang kuat yaitu didukung oleh rekan kerja yang dapat dipercaya serta dapat saling membantu ketika bertugas. Hal tersebut sesuai dengan Luthans et al. (2007), adanya pengaruh positif yang signifikan antara variabel resiliensi karyawan terhadap kinerja didasarkan pada konsep bahwa individu yang tangguh akan lebih mudah beradaptasi dengan perubahan menggunakan keterampilan kreatif mereka dan menghadapi kesulitan secara lebih gigih, serta memiliki kinerja jauh lebih baik lagi seiring keadaan lingkungan kerja yang terus berubah dan menantang

Korelasi signifikan positif antara resiliensi terhadap kinerja perawat diperkuat dengan besar nilai indikator kebugaran perawat yang tinggi. Hal tersebut sejalan dengan Hyo \& Hye (2015), pegawai yang memiliki tingkat resiliensi lebih tinggi akan merespon secara lebih positif terhadap risiko dari pekerjaan yang dilakukan, sehingga faktor resiliensi tersebut menciptakan kecenderungan yang lebih besar untuk mempertahankan performa kerja mereka. Kemampuan perawat dalam mengelola stres juga menunjukkan nilai indikator yang tinggi sehingga resiliensi dapat memberikan dampak kepada perawat untuk pulih dari efek negatif stres kerja, di mana perawat yang tangguh akan semakin tumbuh dan berkembang serta adaptif dalam menghadapi berbagai kesulitan san dapat memberikan kontribusi lebih bagi instansi mereka (Walpita, 2020).

Hasil ini bertentangan dengan Hallak et al. (2018) bahwa resiliensi karyawan tidak memiliki pengaruh positif dan signifikan terhadap kinerja karyawan. Hasil yang berbeda juga terdapat dalam penelitian Lhalloubi \& Ibnchahid (2020) antara resiliensi dan kinerja manajer tidak ada hubungan yang signifikan. Namun dari kedua hasil penelitian tersebut menunjukkan pengaruh positif dan signifikan antara resiliensi dengan kinerja setelah melalui variabel mediasi. Tidak adanya hubungan positif yang signifikan antara resiliensi dan kinerja dikarenakan adanya asumsi bahwa kaitan antara kedua variabel tersebut bukanlah hubungan yang sederhana yang dapat memengaruhi secara langsung.

Hasil pengujian path coefficients diketahui bahwa pengaruh resiliensi karyawan terhadap kinerja karyawan memiliki koefisien estimate dengan nilai yang tinggi. Variabel resiliensi karyawan menjadi kategori faktor yang penting guna meningkatkan kinerja perawat Rumah Sakit Islam Surabaya, apalagi ketika mereka harus bertugas di tengah pandemi Covid-19 yang tentu memiliki risiko tertular virus yang jauh besar sehingga membutuhkan mental yang tangguh serta standart pelayanan dengan protokol kesehatan yang lebih ketat dibandingkan sebelumnya. Dengan adanya bukti ini secara khusus dapat berguna bagi manajer atau kepala bidang keperawatan untuk menyediakan program pelatihan dan pengembangan dalam bidang terkait ketahanan maupun pengaturan aktivitas kerja perawat guna menunjang kinerja perawat yang lebih baik dalam menjalankan tugasnya. Dari analisis di atas serta hasil dari pengujian secara empiris dapat diketahui jika secara signifikan dan positif resiliensi mampu memengaruhi kinerja perawat Rumah Sakit Islam Surabaya, di mana semakin tinggi tingkat resiliensi (ketahanan) dalam diri perawat maka mereka akan menjadi lebih tangguh dan adaptif dalam menjalankan tuntutan kerjanya sehingga kinerjanya juga akan semakin meningkat.

\section{Pengaruh Resiliensi Karyawan terhadap Kepuasan Hidup}

Berdasarkan hasil pengujian, variabel resiliensi karyawan berpengaruh positif dan signifikan terhadap kepuasan hidup. Peningkatan faktor kepuasan hidup pada perawat Rumah Sakit Islam Surabaya dapat diketahui dari beberapa item pernyataan indikator kepuasan hidup diantaranya adalah rasa bersyukur serta kepuasan hidup yang dirasakan oleh perawat saat ini menunjukkan rata-rata nilai yang tinggi. Sehingga hal itu senada dengan Hayat et al. (2016) bahwa resiliensi secara signifikan dan positif memengaruhi kepuasan hidup yang didukung oleh asumsi bahwa faktor pengalaman dan kondisi 
hidup yang sulit akan membuat individu memiliki ketahanan diri tinggi sehingga dapat memprediksi serta menjadi konstruksi yang optimal kesejahteraan seseorang.

Dari hasil kuisioner juga dapat diketahui bahwa indikator resiliensi perawat dalam hal mempertahankan persepsi menunjukkan nilai yang tinggi. Sehingga berkorelasi terhadap penilaian masing-masing individu akan kepuasan hidup yang mereka rasakan. Hal itu memerkuat penelitian Prayag et al. (2019) studi pada perusahaan pasca gempa di Selandia Baru yang menunjukkan jika faktor resiliensi karyawan memiliki korelasi yang positif serta signifikan dengan kepuasan hidup para pelaku bisnis, di mana hal tersebut didukung asumsi bahwa karyawan yang tangguh dalam perusahaan cenderung akan mempunyai kepuasan hidup yang lebih tinggi karena kesejahteraan individu sebagai sebuah faktor internal dalam diri yang penting guna menentukan pemulihan bisnis, sementara kesejahteraan sendiri didorong oleh praktik tangguh dan adaptif individu dalam organisasi mereka.

Faktor lain yang mendukung tingginya tingkat kepuasan hidup perawat adalah tingkat pendapatan para perawat menjadi penunjang dalam bekerja. Berdasarkan hasil analisis dalam penelitian ini menunjukkan bahwa persentase tertinggi rata-rata pendapatan perawat sudah masuk dalam kategori tinggi. Sehingga faktor tersebut yang kemudian mendukung tingginya tingkat kepuasan hidup yang dirasakan oleh perawat di Rumah Sakit Islam Surabaya. Berdasarkan analisis di atas serta hasil dari pengujian secara empiris, resiliensi mampu memengaruhi kinerja perawat Rumah Sakit Islam Surabaya secara positif dan signifikan, di mana semakin tinggi tingkat resiliensi (ketahanan) dalam diri perawat maka tingkat kepuasan hidup yang mereka rasakan juga akan menjadi lebih tinggi.

\section{Pengaruh Kepuasan Hidup terhadap Kinerja Karyawan}

Hasil pengujian, kepuasan hidup tidak berpengaruh signifikan terhadap kinerja karyawan. Meskipun nilai rata-rata dari variabel kepuasan hidup perawat di Rumah Sakit Islam Surabaya masuk dalam kategori tinggi, namun hal tersebut tidak menunjukkan adanya pengaruh yang signifikan terhadap kinerja mereka. Perawat memiliki kinerja yang tinggi dalam menjalankan pekerjaannya terlepas dari seberapa besar tingkat kepuasan hidup yang mereka miliki.

Hasil penelitian ini bertentangan dengan Jones (2006) bahwa semua hubungan antara kepuasan hidup dan ukuran kinerja diketahui signifikan secara statistik. Di mana kepuasan hidup dapat menjadi prediktor terhadap kinerja dari karyawan. Hasil ini juga tidak mendukung Prajogo (2016), secara positif dan signifikan kepuasan hidup berpengaruh terhadap kinerja. Ketika individu memiliki kepuasan hidup yang lebih besar sehingga kinerja yang dihasilkan dapat menjadi lebih tinggi. Hal tersebut terjadi karena individu yang puas akan menggunakan energi terbaiknya dalam pekerjaannya.

Tidak adanya adanya korelasi yang signifikan antara variabel kepuasan hidup dan kinerja tersebut ketika profesi seorang perawat dituntut untuk memberikan pelayanan cepat, tepat dengan tetap menjaga mutu pelayanan, bahkan ditengah risiko tertular virus Covid-19, di mana tenaga kesehatan merupakan titik kontak pertama bagi setiap pasien. Hal tersebut dapat dilihat dari hasil kuisioner terhadap kinerja perawat Rumah Sakit Islam Surabaya yang menunjukkan lebih tinggi jika dibandngkan dengan rata-rata nilai untuk kepuasan hidup mereka. Selain itu faktor sumpah jabatan profesi perawat sebagai kode etik kerja perawat dapat menjadi alasan mengenai tingginya performa perawat dalam menjalankan pekerjaanya meskipun harus bertugas ketika pandemi Covid-19 seperti sekarang. Sehingga terlepas dari tingkat kepuasan hidup masing-masing perawat, mereka tetap menjaga performa kerja dengan maksimal sesuai dengan standart mutu yang sudah ditetapkan oleh instansi, menjalankan nilai dan budaya rumah sakit serta menjalankan tanggung jawab moral perawat sebagai salah satu tenaga kesehatan.

Hasil ini sejalan dengan Chughtai (2019), tidak ada hubungan yang signifikan antara kepuasan hidup terhadap kinerja secara langsung. Namun dalam penelitian tersebut menunjukkan bahwa karyawan yang puas dengan kehidupan mereka cenderung akan mengembangkan hubungan terhadap organisasi tempat mereka bekerja, yang, kemudian memungkinkan mereka untuk bekerja dengan tingkat yang lebih tinggi. 


\section{Pengaruh Resiliensi Karyawan terhadap Kinerja Karyawan melalui Kepuasan Hidup}

Variabel kepuasan hidup tidak berperan signifikan dalam memediasi variabel resiliensi karyawan dengan variabel kinerja. Resiliensi karyawan tidak berpengaruh signifikan terhadap kinerja perawat ketika melalui variabel kepuasan hidup. Hasil pengujian pengaruh secara langsung menunjukkan bahwa hubungan antara variabel resiliensi karyawan terhadap kinerja adalah positif dan signifikan. Tetapi pengujian variabel selanjutnya menyatakan bahwa hubungan antara variabel kepuasan hidup tehadap kinerja perawat tidak memberikan berpengaruh. Perbedaan pengaruh tersebut berdampak pada pengujian secara tidak langsung di mana hipotesis yang memprediksi bahwa kepuasan hidup dapat berperan sebagai mediasi hubungan antara resiliensi karyawan terhadap kinerja ternyata tidak dapat dibuktikan dalam penelitian ini. Sehingga peran variabel kepuasan hidup dalam memediasi resiliensi karyawan dengan kinerja termasuk dalam kategori nomediation, yaitu disebabkan karena salah satu dari path hubungan variabel secara langsung tidak signifikan, sehingga mediasi tidak dapat dipolakan, baik melalui software maupun melalui perhitngan manual.

Meskipun dalam pengujian hubungan antar variabel ditemukan hubungan yang signifikan antara resiliensi karyawan dengan kepuasan hidup namun untuk variabel kepuasan hidup ternyata tidak menunjukkan pengaruh signifikan terhadap kinerja karyawan yang menjadi variabel terikat dalam penelitian ini. Hal tersebut dapat diakibatkan karena tingginya tingkat performa kerja perawat ketika menjalankan tugasnya dipengaruhi oleh tingginya tingkat resiliensi atau ketahanan yang mereka miliki dalam menghadapi berbagai tantangan di tempat kerja serta adaptif dari situasi yang sulit, sehingga terlepas dari kepuasan hidup yang ada pada diri mereka, para perawat terbukti tetap menjaga standart kinerjanya sebagai salah satu tenaga medis, khususnya ditengah pandemi Covid-19 yang menjadikan perawat sebagai titik kontak pertama dengan pasien.

Hasil penelitian ini merupakan salah satu temuan baru yang mengungkapkan hubungan antara resiliensi karyawan terhadap kinerja karyawan menggunakan penambahan variabel kepuasan hidup sebagai mediasi. Meskipun beberapa penelitian sebelumnya juga telah menggunakan variabel kepuasan hidup sebagai mediasi bagi variabel resiliensi karyawan, seperti penelitian dari Prayag et al. (2019). Korelasi antara resiliensi karyawan terhadap kinerja karyawan melalui variabel mediasi kepuasan hidup menunjukkan tidak ada pengaruh yang signifikan. Di mana faktor kepuasan hidup perawat Rumah Sakit Islam Surabaya tidak memediasi faktor resiliensi perawat dalam meningkatkan kinerjanya.

\section{KESIMPULAN}

Berdasarkan hasil pengujian dan pembahasan dalam penelitian ini dapat disimpulkan bahwa resiliensi karyawan berpengaruh positif dan signifikan terhadap kinerja di mana tingginya resiliensi yang dimiliki perawat akan berdampak pada meningkatnya kinerja yang ditunjukkan oleh perawat. Selain itu resiliensi karyawan berpengaruh positif dan signifikan terhadap kepuasan hidup, berarti bahwa perawat yang tangguh akan cenderung memiliki kepuasan hidup yang lebih tinggi karena kesejahteraan karyawan dinilai sebagai faktor internal dalam diri individu. Kepuasan hidup tidak berpengaruh signifikan terhadap kinerja, di mana perawat memiliki kinerja yang tinggi dalam menjalankan pekerjaannya terlepas dari seberapa besar tingkat kepuasan hidup yang dimilikinya. Hubungan antara resiliensi karyawan terhadap kinerja melalui variabel mediasi kepuasan hidup menunjukkan tidak ada berpengaruh yang signifikan. Artinya bahwa faktor kepuasan hidup perawat Rumah Sakit Islam Surabaya tidak memediasi resiliensi perawat terhadap kinerja mereka dalam menajalankan pekerjaanya.

Rumah Sakit dapat menyediakan program pelatihan dan pengembangan dalam bidang terkait ketahanan maupun pengaturan aktivitas kerja perawat guna menjaga kinerja perawat dalam menjalankan menjalankan pekerjaannya untuk menjaga performa para perawat. Berdasarkan faktor kepuasan hidup menunjukkan bahwa perawat cenderung merasa belum mendapatkan hal-hal yang menjadi keinginannya. Hal ini wajar mengingat sebesar $43,7 \%$ dari total responden masih berada di bawah 23 tahun. Di mana perjalanan karir dan pengalaman kerja masih banyak yang akan mereka dapatkan di waktu selanjutnya. Sehingga para perawat dapat menyusun perencanaan karir yang baik 
untuk jagka panjang sehingga mereka dapat mendapatkan apa yang mereka inginkan. Sebab meningkatnya kesejahteraan juga akan meningkatkan kepuasan hidup seseorang sehingga akan membuat individu merasa bahagia dalam menjalani hidupnya.

Keterbatasan penelitian ini adalah periode penelitian dilakukan ketika masih terjadi pandemi Covid-19 dan dilakukan kepada sampel perawat yang tentu memiliki kinerja yang sudah terstandardisasi dalam menjalankan tugasnya sehingga asumsi bias pengukuran antara variabel kepuasan hidup terhadap kinerja besar kemungkinan dapat terjadi. Oleh karena itu untuk kedepannya dapat dilakukan penelitian mengenai variabel kepuasan hidup terhadap kinerja karyawan dengan objek penelitian yang berbeda serta ketika keadaaan lingkungan kerja terlepas dari ancaman penularan virus Covid-19.

\section{DAFTAR PUSTAKA}

Andrews, F. M., \& Withey, S. B. (1976). Social indicators of well-being: America's perception of life quality. New York: Plenum Press.

Ann, A., Alfa, G., Rachmatin, D., \& Agustina, F. (2017). Keputusan Konsumen Dengan Structural Equation Modeling Partial Least Square. EurekaMatika, 5, 59-71. https://ejournal.upi.edu/index.php/JEM/article/view/9599

Athota, V. S., Budhwar, P., \& Malik, A. (2020). Influence of Personality Traits and Moral Values on Employee Well-Being, Resilience and Performance: A Cross-National Study. Applied Psychology, 69(3), 653-685. https://doi.org/https://doi.10.1111/apps.12198

Ayala, J.C., Manzano, G. (2014). The resilience of the entrepreneur. Influence on the success of the business. A longitudinal analysis. J. Econ. Psychol, 42(126-135).

Badan Pusat Statistik. (2020). Survei Dampak COVID-19 terhadap Pelaku Usaha di Indonesia. (https://covid-19.bps.go.id/publikasi/detail/9. diakses pada 2 Februari 2021).

Bardoel, E. A., Pettit, T. M., De Cieri, H., \& McMillan, L. (2014). Employee resilience: An emerging challenge for HRM. Asia-Pacific Journal of Human Resources, 52, 279-297.

Berlemann, M. (2016). Does hurricane risk affect individual well-being? Empirical evidence on the indirect effects of natural disasters. Ecological Economics, 124(99-113.).

Bonnano, G. A. (2005). Clarifying and extending the construct of adult resilience. American Psychologist, 60(265-267).

Budhiasa, S. (2016). Analisis Statistik Multivariate Dengan Aplikasi SEM PLS SMARTPLS 3.2.6 (J. Atmaja (ed.). Udayana Unversity Press. http://udayanapress.unud.ac.id

Chaplin, J. (2006). Kamus Lengkap Psikologi. Jakarta : PT. Raja Grafindo Persada.

Chughtai, A. A. (2019). A Closer Look at the Relationship between Life Satisfaction and Job Performance. International Society for Quality of Life Studies, https://doi.org/https://doi.org/10.1007/s11482-019-09793-2

Clohessy, T., Whelan, E., \& Paradis, K. F. (2020). Does passion for physical activity spillover into performance at work? Examining the direct and indirect effects of passion and life satisfaction on organisational performance and innovativeness. International Journal of Sport and Exercise Psychology, 1-21. https://doi.org/10.1080/1612197X.2020.1766537

Cohn, MA, Fredrickson, BL, Brown, SL, Mikels, JA, \& Conway, A. M. (2009). Happiness unpacked: Positive emotions increase life satisfaction by building resilience. Emotion, 9(3), 361-368. 
Qikki Ocktafian. Pengaruh Resiliensi Karyawan terhadap Kinerja Karyawan melalui Kepuasan Hidup

https://doi.org/10.1037/a0015952

Cooper, C. L., Liu, Y. P., \& Tarba, S. Y. (2014). Resilience, HRM practices and impact on organizational performance and employee well-being. The International Journal of Human Resource Management, Special Issue 25, 2466-2471.

Cropanzano, R., \& Wright, T. A. (2001). When a "happy" worker is really a "productive" worker : A review and further refinement of the happy-productive worker thesis. Consulting Psychology Journal : Practice \& Research, 53, 182-199.

Demiral, Ö. (2018). Commuting Stress-Turnover Intention Relationship and the Mediating Role of Life Satisfaction: An Empirical Analysis of Turkish Employees. Social Sciences, 7(9), 147. https://doi.org/10.20944/preprints201807.0299.v1.

Dewayani, T. (2020). Flexible Working Space (FWS) Sebagai New Normal Kementerian Keuangan Pasca Pandemi Covid-19. (https://www.djkn.kemenkeu.go.id/artikel/baca/13122/FlexibleWorking-Space-FWS-Sebagai-New-Normal-Kementerian-Keuangan-Pasca-Pandemi-Covid19.html, diakses pada 2 Februari 2021).

Diener, E., \& Lucas, R. (2000). Subjective Emotional Well-Being. In M. Lewis \& J. M. HavilandJones (Eds.), Handbook of Emotions. New York : Guilford.

Diener, E., Emmons, R. A., Larsen, R. J., \& Griffin, S. (1985). The satisfaction with life scale. Journal of Personality Assessment, 71-7(49).

Erdogan, B., Bauer, T. N., Truxillo, D. M., \& Mansfield, L. R. (2012). Whistle while you work : A review of the life satisfaction literature. Journal of Management, 38, 1038-1083.

Fisher, R., Maritz, A., \& Lobo, A. (2016). Does individual resilience influence entrepreneurial success. Academy of Entrepreneurship Journal, 22(2), 39-53.

Gito, M., Ihara, H., \& Ogata, H. (2013). The relationship of resilience, hardiness, depression and burnout among Japanese psychiatric hospital nurses. Journal of Nursing Education and Practice, 3(11), 12. https://doi.org/https :// doi.org/10.5430/jnep.v3n11p12

Greguras, G. J., \& Diefendorff, J. M. (2010). Why does proactive personality predict employee life satisfaction and work behaviors? A field investigation of the mediating role ofthe selfconcordance model. Personnel Psychology, 63, 539-560.

Hall, C. M., Malinen, S., Vosslamber, R., \& Wordsworth, R. (2016). Business and post-disaster management: business, organisational and consumer resilience and the christchurch earthquakes. London : Routledge.

Hallak, R., Assaker, G., Connor, P. O., \& Lee, C. (2018). The Effects of Resilience, Creative Selfefficacy, Innovation and Industry Experience. Journal of Retailing and Consumer Services, 40(May 2017), 229-240. https://doi.org/10.1016/j.jretconser.2017.10.014

Hayat, S. Z., Khan, S., \& Sadia, R. (2016). Resilience, wisdom, and life satisfaction in elderly living with families and in old-age homes. Pakistan Journal of Psychological Research, 31(2), 475494. https://doi.org/doi:10.1016/.j.jaging.2012.03.004

Holling, C. S. (1973). Resilience and stability of ecological system. Ecological System, 4 (Annu. Rev.), 1-23.

Hyo, S.J., Hye, H. Y. (2015). The impact of employees positive psychological capital on job 
satisfaction and organizational citizenship behaviors in the hotel. Int. J. Contemp. Hosp. Manag., 27(6), 1135-1156.

Jew, C. L., Green, K. E., \& Kroger, J. (1999). Development and validation of a measure of resiliency. Measurement and Evaluation in Counseling and Development, 32(2), 75-89.

Jones, M. D. (2006). Which is a Better Predictor of Job Performance: Job Satisfaction or Life Satisfaction? Michelle D. Jones Providence College. Management, 1955, 20-43. https://doi.org/http://dx.doi.org/10.1037/t01069-000

Langer, N. (2004). Ketahanan dan spiritualitas: Landasan kekuatan konseling perspektif dengan orang tua. Gerontologi Pendidikan, 30, 611-617.

Kistyanto, A., Budiono, Indawati, N., Fazlurrahman, H., Kautsar, A., \& Rahman, Z. (2018). Food industry performance: Entrepreneurial leadership and human capital perspective. International Journal of Mechanical Engineering and Technology, 9(6), 1199-1208.

Lhalloubi, J., \& Ibnchahid, F. (2020). Do resilience and work engagement enhance distribution manager performance? A study of the automotive sector. Journal of Distribution Science, 18(7), 5-17. https://doi.org/10.15722/JDS.18.7.202007.5

Li, P. P. (2020). Dialogue, Debate, and Discussion Organizational Resilience for a New Normal: Balancing the Paradox of Global Interdependence. Management and Organization Review, 1-7. https://doi.org/10.1017/mor.2020.30

Limnios, E. A. M., R, M., A, G., \& G.M., S. (2014). The resilience architecture framework, four organizational archetypes. Eur. Manag. J. European Management, 32(104-116).

Linnenluecke, M. K. (2017). Resilience in business and management research: A review of influential publications and a research agenda. International Journal of Management Reviews, 1(19), 430 .

Liu, Y. (2018). Organizational Culture, Employee Resilience and Performance in the International Banking Industry. Birkbeck University of London, September, 1-381. bbktheses.da.ulcc.ac.uk

Luthans, F., Youssef, C. M., \& Avolio, B. J. (2007). Psychological capital: Developing the human competitive edge. New York: Oxford University Press.

Mangkunegara, A. (2010). Evaluasi Kinerja SDM. Bandung : PT Revika Aditama.

Margolis, S., Schwitzgebel, E., Ozer, D. J., \& Lyubomirsky, S. (2019). A New Measure of Life Satisfaction: The Riverside Life Satisfaction Scale. Journal of Personality Assessment, 101(6), 621-630. https://doi.org/10.1080/00223891.2018.1464457

Mathis, R. L., \& John H. Jackson. (2008). Human Resource Management (Twelfth Ed, Issue 51). Thomson South-Western. http://ci.nii.ac.jp/naid/40017412209/

McNaughton, R.B., Gray, B. (2017). Entrepreneurship and resilient communities - Introduction to the special issue. J. Enterprising Communities: People Places Glob. Econ., 11 (1)(2-19).

Mungkasa, O. (2020). Bekerja dari Rumah (Working From Home/WFH): Menuju Tatanan Baru Era Pandemi COVID 19. Jurnal Perencanaan Pembangunan: The Indonesian Journal of Development Planning, 4(2), 126-150. https://doi.org/10.36574/jpp.v4i2.119

Nurlaila. (2010). Manajemen Sumber Daya Manusia. Ternate : LepKhair. 
Ong, J. O. \& Mahazan, M. (2020). Strategi pengelolaan sdm dalam peningkatan kinerja perusahaan berkelanjutan di era industri 4.0. Business Economic, Communication, and Social Sciences, 2(1), 159-168.

Prajogo, W. (2016). The Influence Of Work Family Conflict And Work Family Synergy To Emotional Exahustion And Life Satisfaction And Their Influence To Performance. International Conference on Ethics of Business, Economics, and Social Science, 174-187. https://eprints.uny.ac.id/41785/

Prayag, G., Spector, S., \& Orchiston, C. (2019). Current Issues in Tourism Psychological Resilience, Organizational Resilience and Life Satisfaction in Tourism Firms: Insights From The Canterbury Earthquakes. Current Issues in Tourism, 1-18. https://doi.org/10.1080/13683500.2019.1607832

Rahman, M. F. W., Kistyanto, A., \& Surjanti, J. (2020). Flexible work arrangements in Covid-19 pandemic era, influence employee performance: the mediating role of innovative work behavior. International Journal of Management, Innovation \& Entrepreneurial Research, 6(2), 10-22. https://doi.org/10.18510/ijmier.2020.622

Reivich, K. \& Shatte, A. (2002). The Resilience Factor 7 Essential Skills Overcoming Life's Inevitable Obstacles. New York : Random House.

Saoussany, A. M. A. (2018). Measure Individual Job Performance: Its Determinants and Its. Revue Du Contrôle de La Comptabilité et de l'Audit, 356-369.

Sedarmayanti. (2009). Tata Kerja dan Produktivitas Kerja. Bandung : CV Mandar Maju.

Sonnentag, S., Volmer, J., \& Spychala, A. J. (2008). Job performance. The Sage Handbook of Organizational Behavior, 1(427-447).

Staw, BM, Sutton, RI, \& Pelled, L. (1994). Emosi positif karyawan dan hasil yang menguntungkan di tempat kerja. Ilmu Organisasi, 5, 51-68.

Sutrisno, E. (2009). Manajemen Sumber Daya Manusia (Pertama). Jakarta : Kencana.

Taufik, T., \& Ayuningtyas, E. A. (2020). Dampak Pandemi Covid 19 Terhadap Bisnis Dan Eksistensi Platform Online. Jurnal Pengembangan Wiraswasta, 22(01), 21. https://doi.org/10.33370/jpw.v22i01.389

Walpita, Y. N. (2020). High resilience leads to better work performance in nurses: Evidence from South Asia. Journal Nurses Management July 2019, 342-350. https://doi.org/10.1111/jonm.12930

Wang, J., Cooke, F. L., \& Huang, W. (2014). How resilient is the (future) workforce in China ? A study of the banking sector and implications for human resource development. Asia Pacific Journal of Human Resources, 52(132-154).

Welbourne, T. M., Johnson, D. E., \& Erez, A. (1998). The role-based performance scale: Validity analysis of a theory-based measure. Academy of Management Journal, 41 (5)(540-555). https://doi.org/https://doi.org/10. 5465/256941

Williams, L. J., \& Anderson, S. E. (1991). Job Satisfaction and Organizational Commitment as Predictors of Organizational Citizenship and In-Role Behaviors. Journal of Management, 17(3), 601-617. https://doi.org/10.1177/014920639101700305 